\title{
Nutritional Assessment of School Going Girls (7-9 Years) Residing In Urban Areas of Bikaner District, India
}

\author{
Shikatoli Wotsa*, Nisha Choudhary and Madhu Goyal \\ College of Home Science, SKRAU, Bikaner, India \\ *Corresponding author
}

A B S T R A C T

\begin{tabular}{|l|}
\hline K e y w o r d s \\
Nutrition, \\
$\begin{array}{l}\text { Malnutrition, } \\
\text { Recommended } \\
\text { dietary allowances }\end{array}$ \\
\hline Article Info \\
\hline $\begin{array}{l}\text { Accepted: } \\
\text { 22 January } 2019 \\
\text { Available Online: } \\
\text { 10 February } 2019\end{array}$ \\
\hline
\end{tabular}

\section{Introduction}

Nutritional status is a sensitive indicator of child's health. Child malnutrition compromise physical and mental development and weakens immune response, increasing susceptibility to infection. Children are the backbone of a nation and development of any nation depends on the health and well-being of its child population. India has the second largest child population in the world numbering over 2.2 billion worldwide and 263.9 million in India (Census, 2011). Approximately twenty percent of the population in every country constitutes school age children 5-10 years. Globally, malnutrition among school age children is becoming a major public health concern. More than 200 million school age children will be growing up by 2020 with impaired physical and mental development. (Mitra et al, 2007). Developing countries like India accounts for 
about 40 percent of undernourished children in the world and it is largely due to result of dietary inadequacy in relation to their needs.

Selection of foods on the basis of preference without proper judgment aggravates unbalanced diet. This is the due to insufficient knowledge and lack of awareness by the school children and their parents. (Chung et al, 2004). Such dietary habits increase the intake of calorie and thus increase the incidence of overweight, obesity and juvenile diabetes. On the other hand, some of the nutrients such as calcium, vitamin A, thiamine and riboflavin are deficient because of unbalanced diet, eating out, and overflowing processed foods results in the state of nutritional imbalance with over nutrition and nutrition deficiency at the same time (Jung et al., 2002).

It is imperative that dietary patterns of school going children are thoroughly assessed which can help in imbibing simple changes in the daily diet, thus improving their nutritional status. Thus keeping in mind the present study attempts to assess the nutritional status of school going children aged 7 to 9 years was undertaken.

\section{Materials and Methods}

The study was conducted on 7-9 years old school going children studying in elementary schools of Bikaner (Rajasthan) i.e. Central Academy School and Aakashdeep public School. After seeking prior permission and having discussion with the respective school authorities a list of children belonging to the age group of 7-9 years, was prepared. These children were studying either in class $1^{\mathrm{St}} 2^{\text {nd }}$ and $3^{\text {rd }}$ standard. Out of the procured lists, 90 female school children were randomly selected from the two identified schools. Regularity in attending the school was also considered during the study. A well-structured pre-tested interview schedule was developed and used to obtain the requisite information about all the subjects. The subjects $(n=90)$ were assessed for their general information, anthropometric indices, BMI and dietary information.

\section{Anthropometric measurements}

Body measurements which are indicators of underweight, normal, overweight and obesity, were taken and their indices were calculated.

Weight: The mean values were compared with the reference values given by NCHS (ICMR, 2010).

Height: The height measurement was compared with the standard given by NCHS (ICMR, 2010).

Anthropometric measurements i.e., weight and height were measured as per the guidelines suggested by ICMR standards. Height was measured by using a height scale nearest to $0.1 \mathrm{~cm}$. A portable weighing scale was used to measure the weight nearest to $0.1 \mathrm{~kg}$, with minimal clothing and without shoes.

BMI for age according to the $\mathrm{z}$ score was calculated and interpreted as per the method given by WHO (2007) as an indicator for assessing thinness.

Prevalence of malnutrition based on height and weight was assessed with the help of indicator suggested by McLaren (1976).

\section{Dietary survey}

A 24 hours dietary recall method for three consecutive days was adopted to find out the intake of various foods consumed by the subjects.

The data was collected by using standardized cup sets for each day to assess the food and nutrient intake. Raw amounts were quantified either in terms of household measures 
(standardized cups sets) or numbers of these were then converted to raw weight of foods in grams and the nutritive value was calculated using the food consumption tables (Gopalan et al., 1989). The nutrient composition of foods consumed by the subjects was calculated in terms of energy, protein, fat, carbohydrate, $\beta$ carotene, retinol, vitamin $\mathrm{C}$ (ascorbic acid), calcium, and iron by using the food composition tables (Gopalan et al., 1989). Their mean nutrient intakes were compared with RDA given by ICMR (2010) to find out nutrient adequacy ratio (NAR). The NAR represents an index of adequacy for nutrient based on RDA of that nutrient.

\section{Statistical analysis of the data}

The percentage, mean and standard deviation were used to during present study for statistical analysis of the findings.

\section{Results and Discussion}

The result of the study has been categorized and reported as Anthropometric assessment and dietary assessment

\section{Anthropometric assessment}

The physical dimensions of the body are much influenced by nutrition. Selected body measurements therefore can give valuable information about certain type of malnutrition in which body size and body composition are affected. In present study, height and weight, were measured and BMI and depicted in the table and discussed below: Reference value are according to NCHS (ICMR, 2010)

\section{Weight for age}

Weight of an individual indicates the current nutritional status. It is proportional to the dietary intake and any fluctuation may lead to malnutrition of either deficit or excess.
Therefore, weight deficiency may be a precise indicator of the prevalence of protein energy malnutrition among any age group provided age is accurately recorded. During present investigation, the mean weight of all the subjects was recorded as $23.86 \pm 3.35 \mathrm{~kg}$. Age wise mean weight of the subjects were noted to be $20.83 \pm 4.18,23.66 \pm 2.89 \& 27.1 \pm 2.99$ $\mathrm{kg}$ respectively (Table 1 ).

\section{Nutritional status based on weight}

Table 2 exhibits the prevalence of different grades of malnutrition based on McLaren classification using NCHS reference values for body weight of 7-9 years of children. None of the subjects was found to be suffering from severe degree of malnutrition. Majority of the subjects $(53.3 \%)$ remained in normal category followed by moderate malnutrition (26.7\%), mild malnutrition (23.3\%), overweight (18.3\%) and obese (3.3\%).

\section{Height for age}

The height of an individual is influenced both by genetic and environmental factors. The maximum growth potential of an individual is decided by hereditary factors, while the environmental factors, the most important being nutrition and morbidity, determine the extent of exploitation of that genetic potential. Height is affected only by long-term nutritional deprivation; it is considered as an index of chronic or long duration malnutrition (Srilakshmi, 2008).

The mean height of the subjects $(n=90)$ was found to be $126.16 \pm 5.01 \mathrm{~cm}$. Further, age wise mean height of the subjects was recorded as $120.68 \pm 5.25,125.86 \pm 4.81$, and $131.96 \pm$ $4.99 \mathrm{~cm}$ respectively for 7,8 , and 9 years girls. It is clear from the Table 1 that the mean height values were found to be 99.57 to 100.06 percent of the NCHS standards. 
Table.1 Distribution of the subjects according to their height \& weight

\begin{tabular}{|c|c|c|c|c|c|c|}
\hline \multirow{2}{*}{$\begin{array}{c}\text { Age } \\
\text { (in years) }\end{array}$} & \multicolumn{3}{|c|}{ Height } & \multicolumn{3}{|c|}{ Weight } \\
\hline & $\begin{array}{l}\text { Reference value } \\
\text { (NCHS) }\end{array}$ & $\begin{array}{l}\text { Observed value } \\
\text { (cm) }\end{array}$ & $\begin{array}{l}\text { Percentage of } \\
\text { standard value }\end{array}$ & $\begin{array}{l}\text { Reference value } \\
\text { (NCHS) }\end{array}$ & $\begin{array}{l}\text { Observed value } \\
\text { (cm) }\end{array}$ & $\begin{array}{l}\text { Percentage of } \\
\text { standard value }\end{array}$ \\
\hline $7(n=30)$ & 120.6 & $120.68 \pm 5.25$ & 100.06 & 21.8 & $20.83 \pm 4.18$ & 95.55 \\
\hline $8(n=30)$ & 126.4 & $125.86 \pm 4.81$ & 99.57 & 24.8 & $23.66 \pm 2.89$ & 95.40 \\
\hline $9(n=30)$ & 132.2 & $131.96 \pm 4.99$ & 99.81 & 28.5 & $27.1 \pm 2.99$ & 95.08 \\
\hline & & $126.16 \pm 5.01$ & & & $23.86 \pm 3.35$ & \\
\hline
\end{tabular}

Note: Values in parenthesis indicate percentage of the subjects 
Table.2 Distribution of Degree of Malnutrition Based on Weight among Subjects

\begin{tabular}{|c|c|c|c|c|c|c|c|c|}
\hline \multirow{3}{*}{$\begin{array}{l}\text { *Grades of } \\
\text { malnutrition }\end{array}$} & \multicolumn{6}{|c|}{ No. of female subjects } & \multicolumn{2}{|c|}{ Total number } \\
\hline & \multicolumn{2}{|c|}{7 years } & \multicolumn{2}{|c|}{8 years } & \multicolumn{2}{|c|}{9 years } & & \\
\hline & $\mathbf{F}(\%)$ & $\begin{array}{c}\text { Mean wt } \\
(\mathrm{kg})\end{array}$ & $\mathbf{F}(\%)$ & $\begin{array}{c}\text { Mean wt } \\
(\mathrm{kg})\end{array}$ & $\mathbf{F}(\%)$ & $\begin{array}{c}\text { Mean wt } \\
(\mathrm{kg})\end{array}$ & $\mathbf{F}(\%)$ & $\begin{array}{c}\text { Mean wt } \\
(\mathrm{kg})\end{array}$ \\
\hline $\begin{array}{c}<60 \% \\
\text { (Severe } \\
\text { malnutrition) }\end{array}$ & - & & - & & - & & - & \\
\hline $\begin{array}{c}61-80 \% \\
\text { (Moderate } \\
\text { malnutrition) }\end{array}$ & $7(23.3)$ & 15.85 & $2(6.7)$ & 18.5 & $2(6.7)$ & 21.0 & $\begin{array}{c}11 \\
(12.2)\end{array}$ & 18.45 \\
\hline $\begin{array}{c}80-90 \% \\
\text { (Mild malnutrition) }\end{array}$ & $6(20.0)$ & 19.0 & $9(30.0)$ & 21.66 & $6(20.0)$ & 24.33 & $\begin{array}{c}21 \\
(23.3)\end{array}$ & 21.6 \\
\hline $\begin{array}{l}91-110 \% \\
\text { (normal) }\end{array}$ & $12(40.0)$ & 22.08 & $16(53.3)$ & 24.25 & $20(66.6)$ & 27.95 & $\begin{array}{c}48 \\
(53.3)\end{array}$ & 24.76 \\
\hline $\begin{array}{c}110-120 \% \\
\text { (overweight) }\end{array}$ & $4(13.3)$ & 25.25 & $2(6.7)$ & 28.5 & $2(6.7)$ & 33.0 & $8(9.0)$ & 28.91 \\
\hline \multirow[t]{2}{*}{$\begin{array}{c}120 \% \text { and above } \\
\text { (obese) }\end{array}$} & $1(3.4)$ & 34 & $1(3.4)$ & 33 & - & - & $2(2.2)$ & 33.5 \\
\hline & & & & & & & 90 & 25.44 \\
\hline
\end{tabular}

Note: Values in parenthesis indicate percentage of the subjects *McLaren (1976) 
Table.3 Distribution of degree of malnutrition based on height among subjects

\begin{tabular}{|c|c|c|c|c|c|c|c|c|}
\hline \multirow{3}{*}{$\begin{array}{l}* \text { Grades of } \\
\text { malnutrition }\end{array}$} & \multicolumn{6}{|c|}{ Year wise no. of Girls } & \multicolumn{2}{|c|}{ Total number } \\
\hline & \multicolumn{2}{|c|}{7 years } & \multicolumn{2}{|c|}{8 years } & \multicolumn{2}{|c|}{9 years } & \multicolumn{2}{|c|}{ Total } \\
\hline & $\mathrm{F}(\%)$ & Mean & $\mathrm{F}(\%)$ & Mean & $\mathrm{F}(\%)$ & Mean & $\mathrm{F}(\%)$ & Mean \\
\hline $\begin{array}{c}<80 \% \\
\text { (Dwarf) }\end{array}$ & - & & - & & - & & - & \\
\hline $\begin{array}{l}80-93 \% \\
\text { (Short) }\end{array}$ & $2(6.7)$ & 110.0 & $2(6.7)$ & 116.5 & $3(10.0)$ & 123.3 & $7(7.8)$ & 116.6 \\
\hline $\begin{array}{l}93-105 \% \\
\text { (Normal) }\end{array}$ & $25(83.3)$ & 120.6 & $27(90.0)$ & 126.1 & $24(80.0)$ & 126.1 & $76(84.4)$ & 124.3 \\
\hline $\begin{array}{l}>105 \% \\
\text { (Giant) }\end{array}$ & $3(10.0)$ & 128.3 & $1(3.4)$ & 137.0 & $3(10.0)$ & 140.6 & $7(7.8)$ & 135.3 \\
\hline Total subjects & & & & & & & $90(100.0)$ & 125.4 \\
\hline
\end{tabular}

*McLaren (1976)

Note: Values in parenthesis indicate percentage of the subjects 
Table.4 Anthropometric indicators for the subjects (BMI for age)

\begin{tabular}{|c|c|c|c|c|c|c|c|c|c|}
\hline \multirow[t]{2}{*}{$\begin{array}{l}\text { BMI for } \\
\text { age }\end{array}$} & \multirow{2}{*}{ 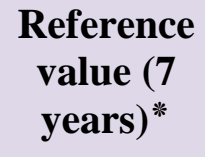 } & \multicolumn{2}{|c|}{$\begin{array}{c}\text { Observed value } \\
\mathbf{n}=\mathbf{3 0}\end{array}$} & \multirow{2}{*}{$\begin{array}{c}\text { Reference } \\
\text { value }(8 \\
\text { years })^{*}\end{array}$} & \multicolumn{2}{|c|}{$\begin{array}{c}\text { Observed value } \\
n=30\end{array}$} & \multirow{2}{*}{ 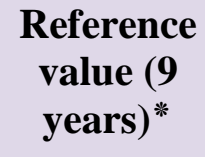 } & \multicolumn{2}{|c|}{$\begin{array}{c}\text { Observed value } \\
\mathbf{n}=\mathbf{3 0}\end{array}$} \\
\hline & & $\mathbf{F}(\%)$ & mean & & F (\%) & mean & & $\mathbf{F}(\%)$ & mean \\
\hline $\begin{array}{c}\text { Severe } \\
\text { undernutrition }\end{array}$ & $<11.8$ & $3(10.0)$ & 13.85 & $<11.9$ & $3(10.0)$ & 11.39 & $<12.1$ & $4(13.3)$ & 11.55 \\
\hline Moderate & 11.8-12.7 & $3(10.0)$ & 12.21 & 11.9-12.9 & $4(13.3)$ & 12.49 & 12.1-13.1 & $4(13.3)$ & 12.73 \\
\hline Normal & $12.7-15.4$ & $17(56.7)$ & 14.35 & 12.9-15.7 & $18(60.0)$ & 14.42 & 13.1-16.1 & $17(56.7)$ & 14.64 \\
\hline Over weight & $15.4-23.3$ & $7(23.3)$ & 16.98 & $15.7-24.8$ & $5(16.7)$ & 16.95 & $16.1-26.5$ & $5(16.7)$ & 17.26 \\
\hline Obesity & $>23.3$ & - & & $>24.8$ & - & - & $>26.5$ & & \\
\hline
\end{tabular}

${ }^{*}$ WHO, 2007. Mean BMI scores. 
Table.5 Mean values of food intake of the subjects

\begin{tabular}{|c|c|c|c|}
\hline Nutrients & Suggested intake* & $\begin{array}{c}\text { Mean } \pm \text { SD } \\
\text { intake }\end{array}$ & $\begin{array}{c}\text { Overall intake } \\
\text { \% of RDI }\end{array}$ \\
\hline Cereals, grains \& products & $180 \mathrm{~g}$ & $176.77 \pm 41.18$ & 98.2 \\
\hline Pulses \& legumes & $60 \mathrm{~g}$ & $32.39 \pm 10.25$ & 53.9 \\
\hline Leafy vegetable & $100 \mathrm{~g}$ & $63.5 \pm 31.8$ & 63.5 \\
\hline Roots \& tubers & $100 \mathrm{~g}$ & $70.52 \pm 39.34$ & 70.5 \\
\hline Other vegetable & $100 \mathrm{~g}$ & $90.66 \pm 37.04$ & 90.6 \\
\hline Fruits & $100 \mathrm{~g}$ & $74.53 \pm 57.45$ & 74.5 \\
\hline Milk \& milk products & $500 \mathrm{ml}$ & $248.06 \pm 93.98$ & 49.6 \\
\hline Fat ( visible) & $30 \mathrm{~g}$ & $28.12 \pm 17.78$ & 93.7 \\
\hline Sugar & $20 \mathrm{~g}$ & $16.46 \pm 4.98$ & 82.3 \\
\hline Nuts \& oil seeds & - & $10.38 \pm 4.77$ & - \\
\hline
\end{tabular}

Note: Values in parenthesis indicate percentage of the subjects $\quad *$ RDI, NIN (2010)

Table.6 Mean nutrient intake of the subjects (7-9 years)

\begin{tabular}{|c|c|c|c|}
\hline Nutrients & Suggested intak** & Mean \pm SD & $\begin{array}{c}\text { Overall intake } \\
\text { \% of RDA }\end{array}$ \\
\hline Energy $(\mathrm{kcal})$ & 1690 & $1417.98 \pm 249.71$ & 83.90 \\
\hline Protein $(\mathrm{g})$ & 29.5 & $39.09 \pm 6.07$ & 132.51 \\
\hline Carbohydrate $(\mathrm{g})$ & 253.5 & $215.87 \pm 34.79$ & 85.15 \\
\hline Fat $(\mathrm{g})$ & 30 & $36.94 \pm 18.3$ & 123.13 \\
\hline$\beta$-carotene $(\mu \mathrm{g})$ & 4800 & $3971.89 \pm 1441.18$ & 82.75 \\
\hline Retinol $(\mu \mathrm{g})$ & 600 & $496.48 \pm 180.14$ & 82.75 \\
\hline Vitamin $\mathrm{C}(\mathrm{mg})$ & 40 & $49.25 \pm 43.14$ & 123.12 \\
\hline Calcium $(\mathrm{mg})$ & 600 & $467.84 \pm 98.60$ & 77.97 \\
\hline Iron $(\mathrm{mg})$ & 16 & $12.37 \pm 6.08$ & 77.31 \\
\hline
\end{tabular}

Note: Values in parenthesis indicate percentage of the subjects *ICMR, 2010 


\section{Nutritional status based on height}

On the basis of height, subjects of present study were categorized in different grades of malnutrition given by McLaren using NCHS standards. Accordingly, majority of them (84.4\%) had normal height as compared to 7.8 percent having giant stature and short heighted. Subjects having less than $80 \%$ of reference height termed as dwarf were not found in present study (Table 3).

\section{Body Mass Index (BMI) for age}

BMI provides a good correlation to fitness and low correlation with stature. It is simple index for weight-for-height that is commonly used to classify underweight, overweight and obesity.

\section{Body Mass Index}

Table 4 indicates that majority of the subjects (56.25-100\%) belonged to normal category BMI with their mean 13.94, 14.26 and 15.11 $\mathrm{kg} / \mathrm{m}^{2}$ for the age group of 7,8 and 9 years respectively .

\section{Overall food intake}

The nutritional status of any individual is directly associated to his food intake. All the individual need a wide range of nutrients to lead a healthy and active life from the foods they consume daily. The components of diet need to be chosen judiciously so that it provides all the nutrients in proper amount and appropriate proportions (ICMR, 1989). The daily intake of various foodstuffs is displayed in table 5 and discussed below with to the recommended balanced diet (IDA, 2011).

Food consumption pattern revealed that the daily mean intake of food groups- cereals, pulses, leafy vegetables, roots and tubers, other vegetables, fruits, milk and milk products, fats and sugar, was found to be lower in percentage than the recommended dietary intake. Similar, the results regarding food intake of children aged 7-9 years in accordance with Sharma and Lakhawat (2016) who also found that the daily mean intake of the food groups was lower than the RDI in the diets of school children of Bhilwara district of Rajasthan. The daily intake of various food groups is displayed in table 5 .

Dietary intake of respondents showed that mean nutrient intake of energy, carbohydrate and other nutrients intake was lower than the Recommended Dietary Allowances as presented in Table 6. The adequacy of Protein, Fat and Vitamin $\mathrm{C}$ intake was higher than RDA.

Hence, it may be concluded that consumption of foods were inadequate in the intake of vegetables, fruits and pulses which resulted into overall lower intake of $\beta$-carotene, calcium and Iron which are very important for a growing child. Although due to high intake of fat, majority of the subjects had normal health status with reference to their body weight. The present finding therefore, opens up a path for further researches on promotion of healthy food habits through nutrition intervention with special reference to vegetables and fruits in school children.

\section{References}

Census (2011). Population of Rajasthan. Internet link: Retrieved from http://www.india onlinepages.com/population/rajasthanpopulation.html dated 27 May 2018.

Chung, S.J, Lee, Y.N and Kwon, S.J, (2004), Factors associated with breakfast skipping in elementary school children in Korea. Korean Journal of Community Nutrition. 9:3-11.

Gopalan, C., Ramasastri, B.V.; and Balasubramanian, S.C. (1989). Nutritive 
value of Indian foods, NIN, ICMR, Hyderabad pp 47-52.

ICMR (2010). Nutrient requirement and recommended allowance for Indians. Indian Council of Medical Research, New Delhi.

Indian Dietetic Association (IDA) (2011).

Jung, S.M, 2002, a study on the nutrition knowledge, the eating attitude, and the eating behavior of elementary school students in Busan. Master's thesis submittes to Dong-A University of Korea.

McLaren, D.S., (1976). W.W.C. classification of nutritional status in early childhood. Lancet, 2: 146-148.

Mitra, M., Kumar, P.V., Chakrabarty, S., Bharati, P. (2007). Nutritional status of Kamar tribal children in Chhatisgarh.
Indian journal of Pediatrics.74: 381-384. National institute of nutrition (NIN) (2010). Nutrient requirement and recommended dietary allowances for Indians. Indian Council of Medical Research, New Delhi.

Sharma, Gitika and Lakhawat, Sarla (2016). Nutritional status of school going children (7-9 years) in rural area of Bhilwara district (Rajasthan). Asian J. Home. Sci., 11 (1): 220-225

Srilakshmi, B. (2008). Nutrition Science ISBN13:978-81-224-2147-7. New age international publishers. www.newagepublishers.com

WHO, 2006, Nutrition for health and Development, World Health Organization, Geneva.

\section{How to cite this article:}

Shikatoli Wotsa, Nisha Choudhary and Madhu Goyal. 2019. Nutritional Assessment of School Going Girls (7-9 Years) Residing In Urban Areas of Bikaner District. Int.J.Curr.Microbiol.App.Sci. 8(02): 3236-3245. doi: https://doi.org/10.20546/ijcmas.2019.802.378 